\title{
Quality Assessment and Application of Red Natural Dye from Beetroot (Beta Vulgaris)
}

\author{
Alim-un-Nisa ${ }^{*}$, Sajila Hina ${ }^{1}$, Imran Kalim ${ }^{1}$, Mohammad Khalid Saeed ${ }^{1}$, Ijaz Ahmad ${ }^{1}$, Naseem Zahra ${ }^{1}$, \\ Sania Mazhar ${ }^{1}$, Shahid Masood ${ }^{1}$, Muhammad Ashraf ${ }^{1}$, Qurat-ul-Ain Syed ${ }^{1}$ and Rabia Shad ${ }^{2}$
}

${ }^{1}$ Food and Biotechnology Research Centre, PCSIR Labs Complex Lahore, Pakistan; ${ }^{2}$ Forman Christian College, Ferozepur Road Lahore, Pakistan.

\begin{abstract}
Beet root (Beta vulgaris) is an excellent source of natural red colorant. In the present work red beet root dye was prepared in the powder form and then candies were prepared using this red beet root dye as food color. The stability studies of both, the prepared red beet dye and candies were performed at different storage conditions $4^{\circ} \mathrm{C}, 25^{\circ} \mathrm{C}, 45^{\circ} \mathrm{C}$ for eight weeks. Betanin content (\%) was measured to evaluate the stability of color which showed the maximum retention of betanin content in red beet dye and candies stored at $4^{\circ} \mathrm{C}$ while lowest \%age of betanin content was observed at $45^{\circ} \mathrm{C}$ showing that at higher temperatures the color is deteriorated. Stability in $\mathrm{pH}$ of red beet dye was also monitored at three different temperatures $\left(4^{\circ} \mathrm{C}, 25^{\circ} \mathrm{C}\right.$ and $45^{\circ} \mathrm{C}$ ). Increase in $\mathrm{pH}$ was observed with increasing storage temperatures. Maximum stability of the color was observed at $4^{\circ} \mathrm{C}$ at most stable acidic $\mathrm{pH}$ and color degradation was observed with gradual increase in $\mathrm{pH}$ at $45^{\circ} \mathrm{C}$. Microbiological analysis of candies and beet powder at $4{ }^{\circ} \mathrm{C}$ and $25^{\circ} \mathrm{C}$ ensure that they are safe for consumption at both storage temperatures.

Received | June 13, 2017; Accepted | March 18, 2021; Published | June 22, 2021

*Correspondence | Alim-un-Nisa, Food and Biotechnology Research Centre, PCSIR Labs Complex Lahore, Pakistan; Email: nisaalim64@ yahoo.com

Citation | Nisa, A., S. Hina, I. Kalim, M.K. Saeed, I. Ahmad, N. Zahra, S. Mazhar, S. Masood, M. Ashraf, Q.A. Syed and R. Shad. 2021. Quality assessment and application of red natural dye from beetroot (Beta vulgaris). Pakistan Journal of Agricultural Research, 34(3): 552-558.

DOI | https://dx.doi.org/10.17582/journal.pjar/2021/34.3.552.558

Keywords | Beet root, Betanin, Microbiological, Stability, Degradation
\end{abstract}

\section{Introduction}

A ppearance of food is an important aspect as we assume about the taste of food from its color most of the times. To enhance the visual attraction towards food products many artificial colors are used in food industry (Clydesdale, 1993; Paakki et al., 2019; Zeide, 2020). Food colors as additives are used in several processed foods for example; candies, soft drinks, sweets and in some prepared dairy products such as cheese and butter. Sometimes these artificial food colors cause allergic responses in children as short term effects while their long term effects result in carcinogenic diseases (Shanmugasundaram et al.,
2019). Due to which some of the colors are prohibited from use in foods especially red (Carocho et al.,2014). The demand of safe and nutritious fresh products with high sensory quality and an appropriate shelf life has been increased in the last decade (Mejia et al., 2020). The use of natural dyes in replacement of synthetic dyes is preferred with increasing awareness about side effects of synthetic dyes particularly in food industry. Natural colors obtained from plants and animals are considered to be safe to use because they are nontoxic, non-carcinogenic and biodegradable in nature (Leong et al., 2018; Rodriguez-Amaya, 2016). The drawback in the use of natural dyes is that these are costly and less stable that's why their use is not that 
easy as yet (Albuquerque et al., 2021; Ravichandran et al., 2014).

Beet root (Beta vulgaris) is a source of water soluble nitrogen-containing pigment, known as betalain or betanin, which is used as food colorant and food additive as well. Betalains have some properties which are beneficial to our health due to which they are also used to enrich food products (Azeredo, 2009). They are also used to enhance the color and flavor of tomato paste, desserts, jams, jellies, ice cream, sauces, sweets and breakfast cereals (Agrawal, 2013; Preethi et al., 2020). Betalains extracted from Beetroot are also known as "beetroot red". Right after the extraction it is exposed to degradation. There are several factors which influence pigment stability for example; temperature, enzymes, $\mathrm{pH}$, light and oxygen (Pedreno and Escribano, 2001). According to Stintzing and Carle (2004). Betalain pigments showed more stability towards $\mathrm{pH}$ and temperature while they are suitable to those foods in which anthocyanin cannot be used as a coloring agent because of low-acid conditions. All these aspects regarding stability make the use of natural food colors less acceptable however there is still an increase in the consumer demand to add up safe and healthy ingredients to their food. This research work is aimed to improve the safety of food products regarding the use of food colors. Red natural color produced from Beetroot (Beta vulgaris) is a safe product to use in different foods. Red natural color is extracted from Beetroot, then this natural colorant is applied to make candies and the color stability at different storage conditions is studied.

\section{Materials and Methods}

\section{Materials}

All the chemicals and reagents used in the current study were of analytical grade, purchased from Merck chemicals (Germany), Scharlau (Spain), Sigma-Aldrich (UK) and Rapid (UK). Beetroot (Beta vulgaris) was procured from the local market of Lahore, Pakistan. The substrate material was then washed thoroughly to remove dust particles and then stored at $4^{\circ} \mathrm{C}$.

\section{Preparation of dye}

Beet roots bought from local marketplace were washed and peeled off. Slices of beet root were placed in hot air oven overnight at $35-40^{\circ} \mathrm{C}$ for drying. Dried slices were grinded in common home grinder to get red beet dye in powder form. Red beet dye powder was stored in polythene bags at $4^{\circ} \mathrm{C}, 25^{\circ} \mathrm{C}$ and $45^{\circ} \mathrm{C}$ for further use.

\section{Application of dye on a food product}

Preparation of candy: $450 \mathrm{~g}$ of sugar was dissolved in $500 \mathrm{~mL}$ distilled water and solution was first slowly heated at $50-60^{\circ} \mathrm{C}$ until all the sugar dissolved and heated to boiling to remove moisture. Glucose syrup $(230 \mathrm{~g})$ was added to the mixture to make it thick and sticky. The heating of the mixture was continued until temperature reaches $150^{\circ} \mathrm{C}$ and resulted in moisture less thick treacle which was kept to cool down till $35^{\circ} \mathrm{C}$.

\section{Application of Dye}

Red beet dye powder was added to treacle kept at $35^{\circ} \mathrm{C}$ to avoid deterioration of color pigments at high temperature. The mixture was homogenized well by manual stirring to obtain uniform color in it. Before complete hardening of the treacle, different shapes of candies were made. Freshly made candies were stored in polythene bags at $4^{\circ} \mathrm{C}, 25^{\circ} \mathrm{C}$ and $45^{\circ} \mathrm{C}$ for further analysis (Figure 1).
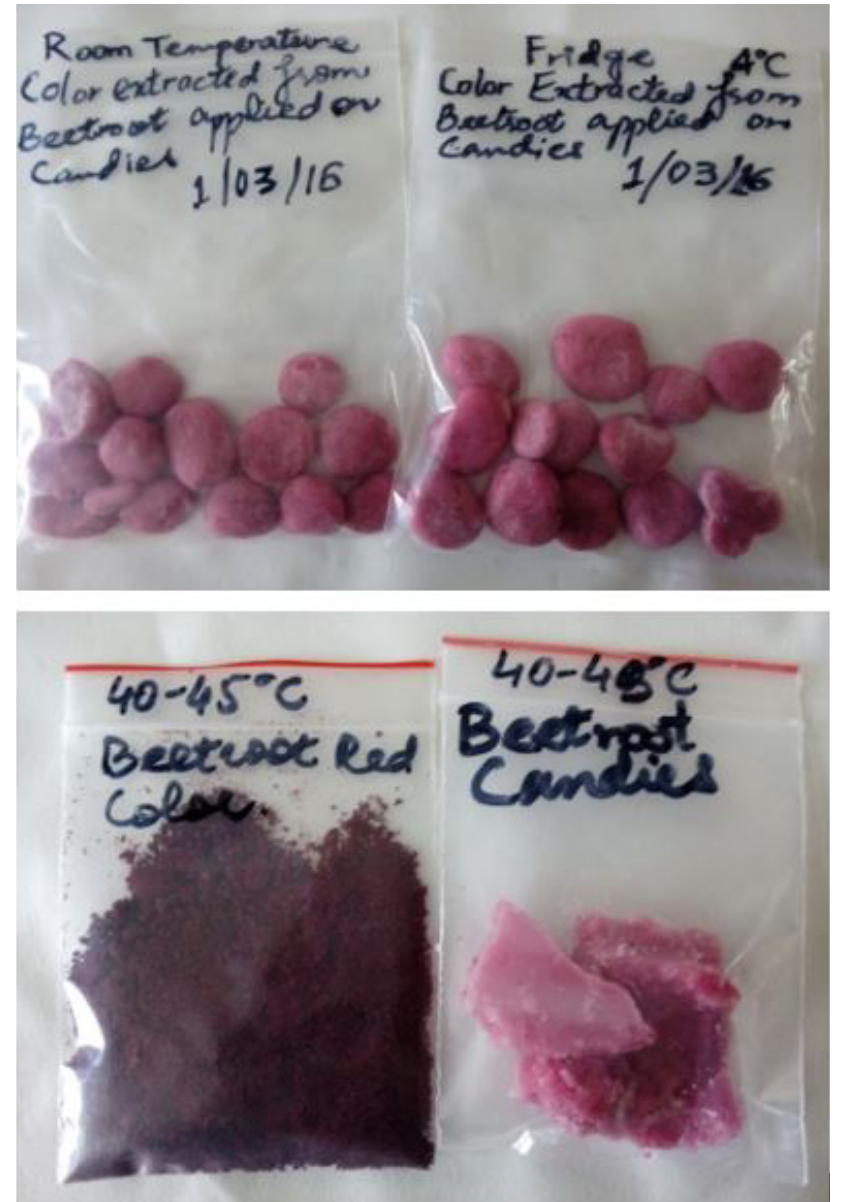

Figure 1: Red beet dye powder and candies stored at different temperatures. 
Spectrophotometric analysis of betanin (\%) in red beet dye and candies

Red beet dye powder and candies were analyzed spectrophotometrically to observe the stability of color as betanin (\%) at $4^{\circ} \mathrm{C}, 25^{\circ} \mathrm{C}$ and $45^{\circ} \mathrm{C} .0 .5 \mathrm{~g}$ of beet powder from each sample stored at $4^{\circ} \mathrm{C}, 25^{\circ} \mathrm{C}$ and $45^{\circ} \mathrm{C}$ was dissolved in McIlvain's phosphate buffer. The solution was centrifuged to take supernatant layer, diluted to $100 \mathrm{~mL}$ with phosphate buffer and then absorbance was measured with water as reference. The maximum absorbance was in the range of 0.2 to 0.8 . The color intensity of batanine in candies was also determined by the same procedure taking $10 \mathrm{~g}$ of each candy stored at $4^{\circ} \mathrm{C}, 25^{\circ} \mathrm{C}$, and $45^{\circ} \mathrm{C}$ in McIlvain's phosphate buffer and diluted thereafter to $100 \mathrm{~mL}$. The color intensity was calculated on the basis of maximum absorbance (at about $530 \mathrm{~nm}$ ), all red coloring matter being included under betanin with specific extinction (FAO, 1984).

$$
\begin{gathered}
E^{1 \%}=1120 \\
1 \mathrm{~cm} \\
\% \text { Beet Red }=A \times V / 1120 \times L \times W
\end{gathered}
$$

In which;

$\mathrm{A}=$ Maximum absorption; $\mathrm{V}=$ volume of test solution measured in $\mathrm{ml}$; $\mathrm{L}=$ length of cell measured in $\mathrm{cm}$; $\mathrm{W}=$ weight of sample in $\mathrm{g}$.

\section{Microbiological analysis of red beet dye and candies}

Candies and dye powder were also analyzed microbiologically to ensure that they are safe for consumption in food. $10 \mathrm{~g}$ of sample was dissolved in $90 \mathrm{~mL}$ Butter Field Phosphate Buffer (BFB). For second dilution $1 \mathrm{~mL}$ of solution mixture was dissolved in $9 \mathrm{~mL}$ BFB. For third dilution $1 \mathrm{~mL}$ from second dilution was dissolved in $9 \mathrm{~mL} \mathrm{BFB}$ again. These solutions were stored in test tubes for further use. Total plate count was carried out using Plate Count Agar (PCA) 20-25 mL/plate, Total coliforms and fecal coliform detection by Lauryl Tryptose Broth Single Strength (LTSS) media, Eosin Methylene Blue (EMB) Agar media for E. coli, XLD and HEA agar for the presence of salmonella., Baird Parker Agar (BPA) and Egg Yolk Agar (EYA) was used to detect staphylococcus aureus and Petro dextrose Agar (PDA) media was used for the detection of yeast and molds in samples. Incubation at $35^{\circ} \mathrm{C}$ for $24-$ 48 hours and at $25^{\circ} \mathrm{C}$ for 5 days for yeast and molds was performed. The analyses were done in triplicates (FAO, 1992).
Stability of red beet dye in $p H$

$\mathrm{pH}$ of the samples of beet powder was measured by a $\mathrm{pH}$ meter to determine the effect of different temperatures on the stability of $\mathrm{pH}$ of the beet powder. Readings of $\mathrm{pH}$ were taken in triplicates after each week in the whole study of 8 weeks.

\section{Statistical analysis}

Spectrophotometric results were analyzed through Mixed Anova Test. These results were analyzed to regulate the significance or non-significance of percent beet in powdered beet dye and candies stored at increasing temperatures with increasing time (Steel et al., 1997).

\section{Results and Discussion}

Storage stability of betanin (\%) in red beet dye and candies Temperature is the most important and influencing factor for the stability of betalain as far as food processing and storage is concerned (Herbach et al., 2006). The betanin content (\%) of red beet powder and candies stored at three different temperatures $\left(4^{\circ} \mathrm{C}, 25^{\circ} \mathrm{C}\right.$ and $\left.45^{\circ} \mathrm{C}\right)$ are presented in Tables 1,2 and Figures 2, 3. According to these results the highest percentage of betanin content was found retained in beet powder and candies stored at $4^{\circ} \mathrm{C}$. While lowest retention of betanin content was observed at $45^{\circ} \mathrm{C}$. This showed that at higher temperatures the color is deteriorated. However, at $25^{\circ} \mathrm{C}$ the retention was lower than the samples stored at $4^{\circ} \mathrm{C}$ and it was higher than the samples stored at $45^{\circ} \mathrm{C}$. Statistical analysis shows that significant results $(\mathrm{P}<0.05)$ obtained from different storage temperatures of beet dye and candies and it is concluded that with increasing storage temperature color degradation is increased. According to reported studies, betalains are heat sensitive pigments so they lose their stability at higher temperatures (Reshmi et al., 2012; Nisa et al., 2015). Saguy et al. (1978) reported that degradation of betalains is increased with increase in temperature and time period of heating. A considerable decrease in betalain stability was observed at 50 and $60^{\circ} \mathrm{C}$ and between 70 and $80^{\circ} \mathrm{C}$ (Havlikova et al., 1983). Thermal degradation of betalain is of great concern because various heat treatments are being used for food preservation to make sure the safety and quality of food products (Paciulli et al., 2016). Thermal stability of betalains according to Herbach et al. (2006) depends on heating time and temperature as well as some other factors such as light concentration and 
structure of the pigment. Another study also reported that degradation of betalain increases progressively with rise in temperature and extended storage time (Halwani et al., 2018). Similarly, significant reduction in betalain content was observed at $40^{\circ} \mathrm{C}$, room temperature and refrigeration temperatures (Mohammed et al., 2021).

Table 1: Stability in Betanin (\%) and $p H$ of red beet dye powder at different temperatures.

\begin{tabular}{lllllll} 
Weeks & \multicolumn{5}{c}{ Red beet dye powder } \\
& $4^{\circ} \mathrm{C}$ & \multicolumn{2}{c}{$25^{\circ} \mathrm{C}$} & \multicolumn{3}{l}{$45^{\circ} \mathrm{C}$} \\
& Betanin (\%) & $\mathrm{pH}$ & Betanin $(\%)$ & $\mathrm{pH}$ & Betanin (\%) & $\mathrm{pH}$ \\
$1^{\text {st }}$ & $0.211 \pm 0.30$ & 4.6 & $0.211 \pm 0.25$ & 4.7 & $0.211 \pm 0.28$ & 4.7 \\
$2^{\text {nd }}$ & $0.210 \pm 0.20$ & 4.7 & $0.201 \pm 0.18$ & 4.9 & $0.201 \pm 0.32$ & 5.0 \\
$3^{\text {rd }}$ & $0.200 \pm 0.10$ & 4.9 & $0.200 \pm 0.10$ & 5.2 & $0.190 \pm 0.05$ & 5.3 \\
$4^{\text {th }}$ & $0.190 \pm 0.09$ & 5.0 & $0.190 \pm 0.09$ & 5.4 & $0.180 \pm 0.19$ & 5.6 \\
$5^{\text {th }}$ & $0.180 \pm 0.20$ & 5.1 & $0.180 \pm 0.20$ & 5.6 & $0.170 \pm 0.08$ & 5.9 \\
$6^{\text {th }}$ & $0.160 \pm 0.05$ & 5.3 & $0.160 \pm 0.17$ & 5.7 & $0.150 \pm 0.35$ & 6.3 \\
$7^{\text {th }}$ & $0.140 \pm 0.15$ & 5.4 & $0.140 \pm 0.20$ & 5.8 & $0.120 \pm 0.33$ & 6.6 \\
$8^{\text {th }}$ & $0.100 \pm 0.25$ & 5.5 & $0.100 \pm 0.09$ & 6.0 & $0.092 \pm 0.29$ & 7.1
\end{tabular}

Table 2: Stability in Betanin (\%) of candies at different temperatures.

\section{Weeks}

\section{Candies}

$\begin{array}{llll} & 4^{\circ} \mathrm{C} & 25^{\circ} \mathrm{C} & 45^{\circ} \mathrm{C} \\ 1^{\text {st }} & 0.00235 \pm 0.02 & 0.00236 \pm 0.06 & 0.00234 \pm 0.08 \\ 2^{\text {nd }} & 0.00230 \pm 0.05 & 0.00230 \pm 0.12 & 0.00226 \pm 0.06 \\ 3^{\text {rd }} & 0.00229 \pm 0.09 & 0.00229 \pm 0.09 & 0.00222 \pm 0.17 \\ 4^{\text {th }} & 0.00222 \pm 0.07 & 0.00223 \pm 0.07 & 0.00204 \pm 0.12 \\ 5^{\text {th }} & 0.00220 \pm 0.10 & 0.00220 \pm 0.16 & 0.00198 \pm 0.09 \\ 6^{\text {th }} & 0.00214 \pm 0.09 & 0.00214 \pm 0.19 & 0.00193 \pm 0.15 \\ 7^{\text {th }} & 0.00204 \pm 0.15 & 0.00207 \pm 0.08 & 0.00185 \pm 0.18 \\ 8^{\text {th }} & 0.00201 \pm 0.08 & 0.00198 \pm 0.15 & 0.00180 \pm 0.16\end{array}$

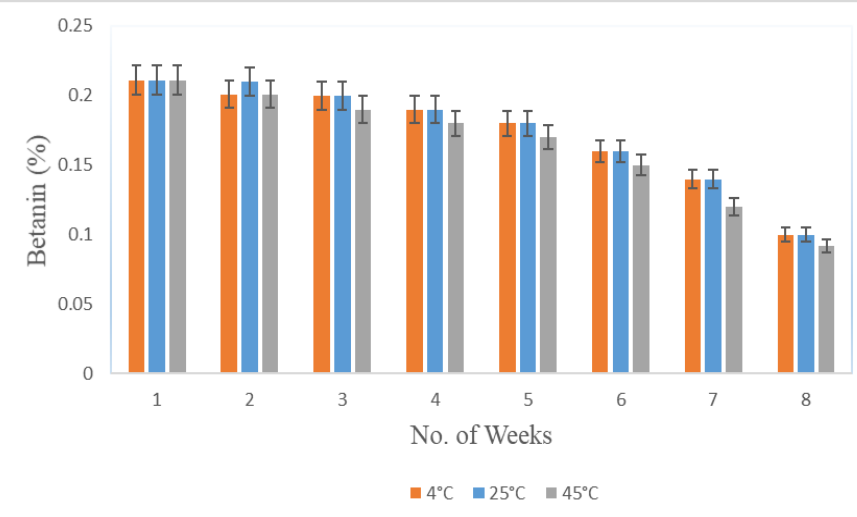

Figure 2: Stability in Betanin (\%) of red beet dye powder at different temperatures.

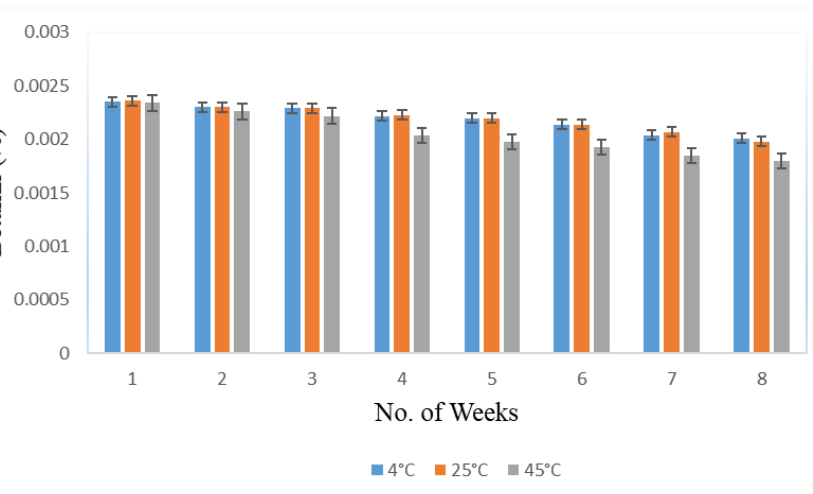

Figure 3: Stability in Betanin (\%) of candy at different temperatures.

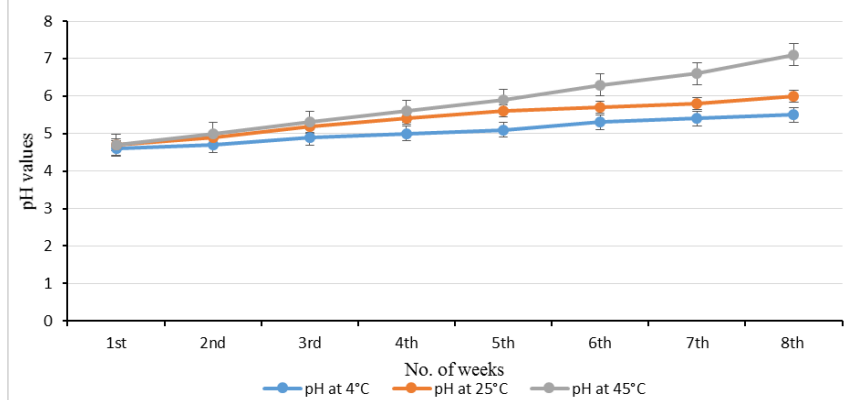

Figure 4: Stability in pH of red beet dye powder at different temperatures.

Table 3: Microbiological analysis of red beet dye powder and candies at different temperatures.

\begin{tabular}{lllll} 
Microorganisms & \multicolumn{2}{l}{$\begin{array}{l}\text { Red beet dye } \\
\text { powder }\end{array}$} & \multicolumn{2}{l}{ Candies } \\
& $4^{\circ} \mathrm{C}$ & $\mathbf{2 5 ^ { \circ } \mathrm { C }}$ & $\mathbf{4}^{\circ} \mathrm{C}$ & $\mathbf{2 5 ^ { \circ } \mathrm { C }}$ \\
Total Plate Count (Cfu/g) & $1.2 \times 10^{3}$ & $1.8 \times 10^{3}$ & $1 \times 10^{3}$ & $2 \times 10^{3}$ \\
Total Coliforms (MPN/g) & $\mathrm{ND}$ & $\mathrm{ND}$ & $\mathrm{ND}$ & $\mathrm{ND}$ \\
Fecal Coliforms (MPN/G) & $\mathrm{ND}$ & $\mathrm{ND}$ & $\mathrm{ND}$ & $\mathrm{ND}$ \\
E.coli (MPN/G) & $\mathrm{ND}$ & $\mathrm{ND}$ & $\mathrm{ND}$ & $\mathrm{ND}$ \\
Staphylococcus aureus/g & $\mathrm{ND}$ & $\mathrm{ND}$ & $\mathrm{ND}$ & $\mathrm{ND}$ \\
Salmonella spp./25g & $\mathrm{ND}$ & $\mathrm{ND}$ & $\mathrm{ND}$ & $\mathrm{ND}$ \\
Yeast count/g & $<10$ & $<10$ & $<10$ & $<10$ \\
Mold count/g & $\mathrm{ND}$ & $<10$ & $\mathrm{ND}$ & $<10$
\end{tabular}

*ND means not detected.

Microbiological analysis of red beet dye and candies

Candies and beet powder were analyzed to ensure that they are safe for consumption. Total plate count, Total coliforms, Fecal coliforms, Staphylococcus aureus, E. coli, Salmonella, Yeast and Mold were determined. Results of Table 2 showed that candy stored at $4^{\circ} \mathrm{C}$ contains total plate count of $1 \times 10^{3}$ $\mathrm{cfu} / \mathrm{g}$ while at $25^{\circ} \mathrm{C}$ it showed total plate count of $2 \times 10^{3} \mathrm{cfu} / \mathrm{g}$. Beetroot powder stored at $4^{\circ} \mathrm{C}$ showed $1.2 \times 10^{3} \mathrm{cfu} / \mathrm{g}$ of total plate count and $1.8 \times 10^{3} \mathrm{cfu} / \mathrm{g}$ at $25^{\circ} \mathrm{C}$. The observed values of total plate count at both temperatures is within standard limits (Codex 
Alimentarius, 2003). Total coliforms, fecal coliforms, E. coli, Staphylococcus aureus and Salmonella were not detected in any sample of candy or beet powder. Yeast was detected in all samples $(<10)$ but the number of yeast colonies were not more than the permitted limit. While mold was detected in candy and powder at $25^{\circ} \mathrm{C}$ but it was within permissible limit. However, mold was not detected in samples of candy and powder stored at $4{ }^{\circ} \mathrm{C}$. Antimicrobial activity of beetroot exhibits restriction of microbial growth (Nisa et al., 2015). Other studies also correlate the antibacterial and antimicrobial effect of beet root extract which is helpful to prevent the food from spoilage (Velicanski et al., 2011; Jasna et al., 2011).

\section{Stability of red beet dye in $\mathrm{pH}$}

Figure 4 shows the $\mathrm{pH}$ of beet powder at three different temperatures $\left(4^{\circ} \mathrm{C}, 25^{\circ} \mathrm{C}\right.$ and $\left.45^{\circ} \mathrm{C}\right)$. According to these results a very slight change in $\mathrm{pH}$ was observed at $4^{\circ} \mathrm{C}$ in the whole time period of 8 weeks. While at $25^{\circ} \mathrm{C}$ the change in $\mathrm{pH}$ was slightly more than $4^{\circ} \mathrm{C}$. However, at $45^{\circ} \mathrm{C}$ highest change in $\mathrm{pH}$ range was observed. The results are in agreement with other studies which showed that degradation of betanin pigment occurs with increase in $\mathrm{pH}$. In a study by Mohammed et al. (2021), the beet root extract was found to be stable at $\mathrm{pH} 3-5$ and the gradual decrease in the betanin stability was observed with increasing $\mathrm{pH}$. Optimum $\mathrm{pH}$ for maximum stability of betanin is between $\mathrm{pH} 5.5$ to 5.8 while oxygen is present. Betalains obtained from beetroot are normally stable at $\mathrm{pH} 5.5$ (Huang and Elbe, 1987). Betalains extracted from Amaranths species exhibited maximum stability at $\mathrm{pH} 5-7$ at $25^{\circ} \mathrm{C}$ (Cai et al., 1999). Castellar et al. (2003) experimented that Betacyanins of Opuntia showed thermal stability at $\mathrm{pH}$ 5.0. Elbe et al. (1981) found that betanine solution in the presence of nitrogen is most stable at $\mathrm{pH} 4.0-5.0$. Betanine degradation in solution is reversible (Huang and Elbe, 1987). Partial regeneration of betanine was experimented first after heating and results showed that amount of regeneration of the pigment depends on the $\mathrm{pH}$ of the sample (Elbe et al., 1981). Czapski (1985) noted the maximum regeneration of betanine affected by the storage temperature and the type of buffer solution. Betalain solution at $\mathrm{pH}$ 4.75 when kept at room temperature for 130 minutes after heating showed an increase in retention from 54\% to 92\% (Elbe et al., 1981). Czapski (1985) also obtained similar results in other studies of betanine regeneration. Hydrolysis of the aldimine bond may attributed as a possible cause of the degradation of the betanin under alkaline conditions $\mathrm{pH}>7$ (Herbach et al., 2006).

\section{Conclusions and Recommendations}

The aim of the present research work is to promote the use of natural red dye obtained from Beetroot (Beta vulgaris) by replacing the synthetic red food dye with this natural one for making candies and then studying its stability in the prepared candies at different storage conditions $4^{\circ} \mathrm{C}, 25^{\circ} \mathrm{C}, 45^{\circ} \mathrm{C}$ for eight weeks. Stability in terms of betanin content (\%) showed maximum retention at $4^{\circ} \mathrm{C}$ while lowest \%age of betanin content was observed at $45^{\circ} \mathrm{C}$ showing that at higher temperatures the color is deteriorated. Increase in $\mathrm{pH}$ was observed with increasing storage temperatures. Maximum stability of the color was observed at $4^{\circ} \mathrm{C}$ at most stable acidic $\mathrm{pH}$ and color degradation was observed with gradual increase in $\mathrm{pH}$ at $45^{\circ} \mathrm{C}$. The results are encouraging as this natural red beet dye is safe to use in candies because deterioration of color was observed only at high temperatures and $\mathrm{pH}$. Moreover, microbiological analysis ensures the safety of natural red beet dye in candies. Therefore, it can safely be concluded that use of red beet natural colorant in product like candies which are more consumable items of children should be promoted. However, there is a need to explore different methods to increase the color stability of dye obtained from beetroot at high temperature.

\section{Novelty Statement}

To the best of our knowledge, application of natural red dye in candies and its stability studies is novel work.

\section{Author's Contribution}

Alim-un-Nisa: Conceived the idea and product development. Technical input at every step.

Sajila Hina: Did experimental work, overall management of the article.

Imran Kalim: Methodology spectrophotometric analysis.

Muhammad Khalid Saeed, Shahid Masood and Muhammad Ashraf: Methodology, stability studies. Ijaz Ahmad: Technical input at every step.

Naseem Zahra: Experimental work, data compilation and analysis. 
Sania Mazhar: Methodology, microbiological analysis.

Qurat-ul-Ain Syed: Technical input at every step.

Rabia Shad: Result and discussion, introduction, references.

\section{Conflict of interest}

The authors have declared no conflict of interest.

\section{References}

Agrawal, A., 2013. Scope of betalains as a food colorant. Int. J. Adv. Sci. Tech. Res., 3(3): 22-36.

Albuquerque, B.R., M.B.P.P. Oliveira, L. Barros and I.C.F.R. Ferreira. 2021. Could fruits be a reliable source of food colorants? Pros and cons of these natural additives. Crit. Rev. Food Sci. Nutr., 61(5): 805-835. https://doi.org/10.1080 /10408398.2020.1746904

Azeredo, H.M.C., 2009. Betalains: properties, sources, applications, and stability. A review. Int. J. Food Sci. Tech., 44: 2365-2376. https:// doi.org/10.1111/j.1365-2621.2007.01668.x

Cai, Y. and H. Corke. 1999. Amaranthus betacyanin pigments applied in model food systems. J. Food Sci., 64(5): 869-873. https:// doi.org/10.1111/j.1365-2621.1999.tb15930.x

Carocho, M., M.F. Barreiro, P. Morales and C.F.R. Isabel. 2014. Adding molecules to food, pros and cons: A review on synthetic and natural food additives. Comp. Rev. Food Sci. Food Saf., 13: 377-399. https://doi.org/10.1111/15414337.12065

Castellar, R., J.M. Obon, M. Alacid and J.A. Fernandez-Lopez. 2003. Color properties and stability of betacyanins from Opuntia fruits. J. Agri.c Food Chem., 51(9): 2772-2776. https:// doi.org/10.1021/jf021045h

Clydesdale, F.M., 1993. Color as a factor in food choice. Crit. Rev. Food Sci. Nutr., 33: 83-101. https://doi.org/10.1080/10408399309527614

Codex Alimentarius Commission, 2003. Joint $\mathrm{FAO} / \mathrm{WHO}$ food standards programme, codex coordinating committee for the Near East, 2nd Session, Cairo, Egypt, January 20-23.

Czapski, J., 1985. The effect of heating conditions on losses and regeneration of betacyanins. Z. Lebensm. Unters. Forsch., 180(1): 21-25. https://doi.org/10.1007/BF01042906

Elbe, J.H., S.J. Schwartz and B.E. Hildenbrand. 1981. Loss and regeneration of betacyanin pigments during processing of red beets. J. Food Sci., 46(6): 1713-1715. https://doi. org/10.1111/j.1365-2621.1981.tb04470.x

FAO Food and Nutrition Paper 31/1. 1984. Specifications for identity and purity of food colours, FAO of the United Nations.

Halwani, A.F., H.A. Sindi and H.A. Jambi. 2018. Characterization of physical properties of red beet pigments. J. Biochem. Tech., 9(2): 16.

Havlikova, L., K. Mikov and V. Kyzlink. 1983. Heat stability of betacyanins. Z. LebensmittelUntersuchung Forschung. 177(4): 247-250. https://doi.org/10.1007/BF01082487

Herbach, K.M., F.C. Stintzing and R. Carle. 2006. Betalain stability and degradation structural and chromatic aspects. J. Food Sci., 71(4): R41-R50. https://doi.org/10.1111/j.17503841.2006.00022.x

Huang, A.S. and J.V. Elbe. 1987. Effect of $\mathrm{pH}$ on the degradation and regeneration of betanine. J. Food Sci., 52(6): 1689-1693. https://doi. org/10.1111/j.1365-2621.1987.tb05907.x

Jasna, M., S.S. Canadanovic-Brunet, G.S. Savatovic, J.J. Cetkovic, S.M. Vulic, L.M.D. Sinisa and D.C. Dragoljub. 2011. Antioxidant and antimicrobial activities of beet root pomace extracts. Czech. J. Food Sci., 29: 575-585. https://doi.org/10.17221/210/2010-CJFS

Leong, H.Y., P.L. Show, M.H. Lim, C.W. Ooi and T.C.Ling. 2018. Natural red pigments from plants and their health benefits: A review. Food Rev. Int., 34(5): 463-482. https://doi.org/10.10 80/87559129.2017.1326935

Manual of Food Quality Control 4. Rev.1. 1992. Microbiological Analysis, FAO Food and Nutrition Paper 14/4 Rev.1. Chapter 2, FAO of the United Nations.

Mejia, E.G., Q. Zhang, K. Penta, A. Eroglu and M.A. Lila. 2020. The colors of health: Chemistry, bioactivity, and market demand for colorful foods and natural food sources of colorants.Ann. Rev. Food Sci.Tech., 11(1): 145182. https://doi.org/10.1146/annurevfood-032519-051729

Mohammed, A.N., S.P. Ishwarya and P. Nisha. 2021. Nanoemulsion versus microemulsion systems for the encapsulation of beetroot extract: comparison of physicochemical characteristics and betalain stability. Food Bioprocess. Technol., 14: 133-150. https://doi. org/10.1007/s11947-020-02562-2 
Nisa, A., K. Saeed, S. Hina, N. Zahra, S. Mazhar, I. Kalim and Q. Syed. 2015. Nutritional, antioxidant, microbiological and toxicological studies on red dye extracted from red beet roots (Beta vulgaris). Res. J. Chem. Sci., 5(4): 1-6.

Paakki, M., I. Aaltojarvi, M. Sandell and A. Hopia. 2019. The importance of the visual aesthetics of colours in food at a workday lunch. Int. J. Gastron. Food Sci., 16: 100131. https://doi. org/10.1016/j.ijgfs.2018.12.001

Paciulli, M., I.G. Medina-Meza, E. Chiavaro and G.V. Barbosa-Canovas. 2016. Impact of thermal and high pressure processing on quality parameters of beetroot (Beta vulgaris L.). LWT-Food Sci. Tech., 68: 98-104. https:// doi.org/10.1016/j.1wt.2015.12.029

Pedreno, M.A. and J. Escribano. 2001. Correlation between antiradical activity and stability of betanine from Beta vulgaris $\mathrm{L}$ roots under different $\mathrm{pH}$, temperature and light conditions. J. Sci. Food Agric., 81(7): 627-631. https://doi. org/10.1002/jsfa.851

Preethi, R., S.M. Deotale, J.A. Moses and C. Anandharamakrishnan. 2020. Conductive hydro drying of beetroot (Beta vulgaris L) pulp: Insights for natural food colorant applications. J. Food Process Eng., 43(12): e13557. https:// doi.org/10.1111/jfpe.13557

Ravichandran, K., R. Palaniraj, N.M.M.T. Saw, A.M. Gabr, A.R. Ahmed, D. Knorr and I. Smetanska. 2014. Effects of different encapsulation agents and drying process on stability of betalains extract. J. Food Sci. Tech., 51(9): 2216-2221. https://doi.org/10.1007/ s13197-012-0728-6
Reshmi, S.K., K.M. Aravindhan and P.S. Devi. 2012. The effect of light, temperature, $\mathrm{pH}$ on stability of betacyanin pigments in basella alba fruit. Asian J. Pharm. Clin. Res., 4(3): 107-110.

Rodriguez-Amaya, D.B., 2016. Natural food pigments and colorants. Curr. Opin. Food Sci., 7: 20-30. https://doi.org/10.1016/j. cofs.2015.08.004

Saguy, I., I.J. Kopelman and S. Mizrahi. 1978. Thermal kinetic degradation of betanin and betalamic acid. J. Agric. Food Chem., 26(2): 360-362. https://doi.org/10.1021/jf60216a052

Shanmugasundaram, P., Bavenro and T. Rujaswini. 2019. A review on food coloring agents safe or unsafe? Res. J. Pharm. Tech., 12(5): 2503-2505. https://doi.org/10.5958/0974360X.2019.00421.9

Steel, R.G.D., J.H. Torrie and D.A. Dicky. 1997. Principles and procedures of statistics: A biometrical approach. $3^{\text {rd }}$ edn. McGraw Hill Book Co. Inc., New York.

Stintzing, F.C. and R. Carle. 2004. Functional properties of anthocyanins and betalains in plants, food, and in human nutrition. Trends Food Sci. Tech., 15(1): 19-38. https://doi. org/10.1016/j.tifs.2003.07.004

Velicanski, A.S., D.D. Cvetkovic, S.L. Markov, J.J. Vulic and S.M. Dilas. 2011. Antibacterial activity of Beta vulgaris L. pomace extract. Acta Period. Tech., (42): 263-269. https://doi. org/10.2298/APT1142263V

Zeide, A., 2020. Visualizing taste: How business changed the look of what you eat. By $\mathrm{Ai}$ Hisano. Environ. Hist., 25(4): 800-802. https:// doi.org/10.1093/envhis/emaa038 